\title{
On the Continued Reconstruction of the History of Nephrology
}

\author{
Garabed Eknoyan Natale G. De Santo Shaul Shasha Guido Bellinghieri \\ Vincenzo Savica Shaul G. Massry
}

The Third Congress of the International Association for the History of Nephrology (IAHN) was originally scheduled to be held on October 29 to November 1, 2000, in Jerusalem. Unfortunately, the disturbing events that began to unfold in Israel in the fall of that year necessitated the cancellation of the Congress the week before the anticipated meeting. While the initial intent was to reschedule the meeting in Jerusalem in the spring of 2001, the continuous and accelerating local turmoil soon made it evident that this would be an unlikely possibility in the immediate future. It was only then that another venue was sought in the summer of 2001. Professors Guido Bellinghieri and Vincenzo Savica of the Faculty of Medicine of the University of Messina were kind enough to volunteer to host the Congress in Taormina, Sicily, on November 15-18, 2001. Regrettably, the short lead time available did not permit public announcements of the Congress and the limited available resources allowed only the presenters of the original program to be notified and invited.

The Congress was held under the auspices of the President of Sicily Region, the Italian Society of Nephrology, the Minister of Health of Sicily Region, the University of Messina and its Faculty of Medicine, the President of the Province of Messina, the Mayor of Messina, the Order of Medical Doctors of Messina, AAPIT of the City of Messina and the Opera of the University of Messina. All were represented at the opening ceremony of the Congress.
During the opening ceremony Honorary Membership Medals were presented to Professors Ori S. Better, Charles Kleeman, Silvana Favaro and Taddeus Orlowski.

The meetings were held in the bucolic Hotel San Domenico in Taormina, Sicily. Appropriately, the hotel was once a Dominican monastery and center of learning for the preservation and reproduction of manuscripts, with its scriptorium and appropriate accoutrements. The sessions were held in what used to be the church of the monastery, and what used to be the altar served as the podium of the session chairs. The program of the congress, with a few exceptions, was the one developed for presentation in Jerusalem by the Program Committee of that meeting, consisting of Shaul Shasha, Shaul G. Massry, Ori S. Better, Natale G. De Santo, Garabed Eknoyan and Shmel Kotek.

The IAHN was founded in 1994, in response to interest expressed at an International Conference on the History of Nephrology organized by Natale G. De Santo and held in Naples, Italy, on October 14-16, 1993. Subsequent congresses were held under the banner of the IAHN in Kos, Greece, on October 14-16, 1996, and in Padua, Italy, on October 4-7, 1998. The proceedings of those meetings have been published as the History of Nephrology 1,2, and 3. The proceedings of the meeting in Taormina are now presented as the History of Nephrology 4, published as a bound volume as well as a special issue of the American Journal of Nephrology.

\begin{tabular}{ll}
\hline KARGER & ( ) 2002 S. Karger AG, Basel \\
0250-8095/02/0223-0097\$18.50/0 \\
$\begin{array}{l}\text { Fax +4161306 12 34 } \\
\begin{array}{l}\text { E-Mail karger@karger.ch } \\
\text { www.karger.com }\end{array}\end{array}$ & $\begin{array}{l}\text { Accessible online at: } \\
\text { www.karger.com/journals/ajn }\end{array}$
\end{tabular}


Progress made in reconstituting the history of nephrology is evident from the variety of subjects covered and the depth of content of the proceedings of the Congress offered in the present volume. This has been possible only through the effort and interest of the participants in exploring information on diseases of the kidney in various medical texts of the past, where it had been buried heretofore. This is well exemplified in the section on History of Diseases of the Kidney presented at the Third Congress of the IAHN that appears in the present volume. It is evident that physicians have toiled in diagnosing and treating ailments of the kidney for millennia, well before the emergence of the specialty of nephrology. It is evident also that many of the best minds in medicine when faced with the same complex of signs and symptoms, we now classify as diseases of the kidney, were initially puzzled by them and then satisfied by merely describing them. While the flowering of anatomy allowed the attribution of some of these clinical manifestations to pathologies of the kidney observed at autopsy, it was only after the Scientific Revolution and during the Enlightenment that most of these descriptive entities came to be grouped under the taxonomic terms by which any medical student today can make a specific diagnosis of kidney disease. Their treatment, whether symptomatic or curative, had to await the post World War II period of blossoming basic research before they could get passed the Galenic dogma that had guided therapy until then: 'All who drink of this remedy recover in a short time except those whom it does not help, who all die. Therefore, it is obvious that it fails only in incurable cases.'

In helping reconstruct the history of diseases that constitute the matrix of nephrology, the IAHN has entered a new phase in its evolution. Following the session on the Origins of Renal Physiology, which appeared in History of
Nephrology 3, the piece-by-piece reconstruction of the components of the edifice which constitutes the history of nephrology has begun. Considerable more work will be needed to erect the full edifice. Future congresses of the IAHN should help make this possible. The Fourth Congress of the IAHN will be held in 2003. It is anticipated that that meeting will continue to assemble and expand on the remaining parts of the edifice of the history of nephrology.

At the closing Business Meeting of the Association in Taormina, the following officers were elected to serve for 2001-2003: Spyros Marketos, President; Charles George, Vice President; Garabed Eknoyan, Secretary-Treasurer, and Marc De Broe, Athanasias Diamandapoulos, Eva Kinne-Safran, Sandor Sonkodi and Alain Touwaide, Concillors. In addition the immediate past president, Shaul G. Massry, will join Natale G. De Santo as ex-officio Councillor to serve on the Board of Directors.

Also, at the Business Meeting the Board acknowledged the loss of two ardent supporters of the IAHN: Professor Domenico Mancino (1936-2001), who hosted the inaugural International Conference of Nephrology in Naples in 1993, and Professor Vincenzo Mezzogiorno (1926-2001), who had participated in every meeting of the IAHN, and whose prepared presentation for this Congress was delivered by his co-worker and son, Antonio Mezzogiorno. In recognition of their support of the mission of the IAHN their obituaries are reproduced here as a memorial tribute to their many contributions to the history of medicine in general and that of nephrology in particular.

In closing, acknowledgements are due to the following organizations for their generous support of the Third Congress of the IAHN: Bellco; Dompe Biotec; Gambro; Genzyme; Hospal; Jannsen Cilag; Merck Sharp \& Dohme; Pfizer; Roche, and Terumo.
$98 \quad$ Am J Nephrol 2002;22:97-98
Eknoyan/De Santo/Shasha/Bellinghieri/ Savica/Massry 